\title{
The Death Sentence That Is America's TOXIC PRISONS
}

\author{
TAYLOR CARPENTER ${ }^{*}$
}

\section{INTRODUCTION}

Seeing inequity in the environmental protection of their communities, concerned citizens started the environmental justice movement in the 1960s, and attempted to address the burden of environmental harms on minority and lowincome communities. ${ }^{1}$ The environmental justice movement strives for "the fair treatment and meaningful involvement of all people regardless of race, color, national origin, or income, with respect to the development, implementation, and enforcement of environmental laws, regulations, and policies." ${ }^{\text {All peoples }}$ having the same protection from environmental and health hazards and having equal access to the decision-making for a healthy community is ultimately the goal of the movement. ${ }^{3}$ Our country's inmates suffer from environmental injustice and have been largely left out of the movement until fairly recently. ${ }^{4}$ However, the inmates' plight is a pressing environmental justice issue because of their exposure to environmental and health hazards, and the large number of incarcerated minorities. ${ }^{5}$

The health and environmental hazards in prisons disproportionately impact minority populations because minority populations are disproportionately incarcerated. ${ }^{6}$ For example, in Indiana, whites makeup eighty-two percent of the total population, but only comprise fifty-nine percent of the incarcerated population. ${ }^{7}$ In contrast, blacks make up thirty-four percent of the incarcerated population while only making up nine percent of the total population. ${ }^{8}$ This

* Indiana University Robert H. McKinney School of Law, J.D. Candidate, 2020; Bachelor of Arts, 2016, University of Georgia.

1. Environmental Justice, U.S. Envtl. Protection Agency, https://www.epa.gov/ environmentaljustice [https://perma.cc/RK4Y-98YQ].

2. $I d$.

3. $I d$.

4. Andrea C. Armstrong, Death Row Conditions Through an Environmental Justice Lens, 70 ARK. L. REV. 203, 207 (2017).

5. Nathalie Prescott, Prisoner (In)consideration in Environmental Justice Analyses, GEO. ENVTL. L. REV. ONLINE (2016).

6. Leah Sakala, Breaking Down Mass Incarceration in the 2010 Census: State-by-State Incarceration Rates by Race/Ethnicity, PrisOn PoL'y InITIATIVE (May 28, 2014), https://www. prisonpolicy.org/reports/rates.html [https://perma.cc/YXL7-KRTD].

7. Graph showing Whites are Underrepresented in Indiana Prisons and Jails, PRISON POL'Y INITIATIVE, https://www.prisonpolicy.org/graphs/2010percent/IN_Whites_2010.html [https://perma.cc/L5SP-YMUR].

8. Graph showing Blacks are Overrepresented in Indiana Prisons and Jails, PRISON POL'Y INITIATIVE, https://www.prisonpolicy.org/graphs/2010percent/IN_Blacks_2010.html[https://perma. cc/BD6V-DBPF]. 
disparity illustrates why inmates need to be included in the environmental justice movement - it's supposed to protect these vulnerable groups of people. ${ }^{9}$

So far, the discussions examining inmate health through an environmental justice lens has largely focused on the building sites for new prisons.$^{10}$ However, the recent addition of the prison layer to the Environmental Protection Agency's (hereinafter "EPA") "Environmental Justice and Screening Tool" is an example of the positive progress in this area. ${ }^{11}$ According to the EPA, the tool uses national data and amalgamates environmental and demographic indicators into maps and reports. ${ }^{12}$ The tool allows users to find areas with: "minority and/or low-income populations, potential environmental quality issues, [and] a combination of environmental and demographic indicators that is greater than usual." 13 The prison layer allows users to analyze the location of prisons, jails, and detention centers in relation to environmental hazards. ${ }^{14}$ The addition of the prison layer is a big step for the growing national movement of environmental justice for inmates and for analyzing prisons from an environmental justice perspective. ${ }^{15}$

As the discussion surrounding the environmental and health hazards of prisons progresses, our country needs to start examining legal solutions to the problem - solutions that will lead to fewer exposures and better quality of life for those men and women who are forced to live in a particular place.

\section{TOXIC PRISONS}

There are different types of exposures in different prisons across the country. ${ }^{16}$ Inmates' conditions vary from breathing in coal ash to exposure to nuclear waste, which illustrates why there is no one simple solution to the problem. ${ }^{17}$ However, this country cannot allow this problem to continue and let a simple prison sentence essentially become a death sentence for those inmates who are exposed to these toxins.

9. Prescott, supra note 5.

10. Armstrong, supra note 4, at 213-14.

11. Zoe Loftus-Farren, EPA Adds Prison Locations to Its Environmental Justice Mapping Tool, ECO WATCH (Sept. 21, 2017), https://www.ecowatch.com/prison-locations-environmentaljustice-2488013644.html [https://perma.cc/7KW5-4FM3].

12. EJSCREEN: Environmental Justice Screening and Mapping Tool, EnVtL. Prot. AGENCY, https://www.epa.gov/ejscreen [https://perma.cc/BG9J-Y3E4].

13. Purposes and Uses of EJSCREEN, ENVTL. Prot. AGENCY, https://www.epa.gov/ejscreen/ purposes-and-uses-ejscreen [https://perma.cc/L3DE-NTUS].

14. Loftus-Farren, supra note 11.

15. Id.

16. Candice Bernd, Maureen Nandini Mitra \& Zoe Loftus-Farren, America's Toxic Prisons: The Environmental Injustices of Mass Incarceration, TRUTHOUT (Jun. 1, 2017), https://truthout.org/ articles/america-s-toxic-prisons-the-environmental-injustices-of-mass-incarceration/ [https://perma.cc/RLC2-HHSC].

17. $I d$. 
This note will explore four examples of toxic prisons or detention centers already in operation and one currently being built that could potentially cause similar health concerns in later years. These toxic prisons and detention centers are unconstitutional and should not be in operation.

\section{A. Coal Ash Exposure-SCI Fayette (Pennsylvania)}

As of February 28, 2019, Fayette State Correctional Institute was at 98.8 percent capacity with its total institute population at $2,104 .{ }^{18}$ The Pennsylvania General Assembly voted to authorize the facility in 1997; ground was broken in March of 2000, and the inmates arrived in August of 2003. ${ }^{19}$ The facility is located on a corner of "what, in the 1940s through the 1970s, was once one of the largest coal preparation plants in the world." ${ }^{20}$ Here the coal was washed and graded, and the clean coal was sent off, and the leftover coal refuse was dumped at the site. ${ }^{21}$ By the mid-1990s, about 40 million tons of coal refuse had been dumped at the site. ${ }^{22}$ The site was eventually purchased by a local company that partnered with the Pennsylvania Department of Environmental Protection to dump a different type of coal byproduct on the site - coal ash. ${ }^{23}$ Coal ash is a waste produced when coal is burned at power plants; more than 5 million tons of coal ash has been dumped at the site since $1997 .{ }^{24}$

Coal ash is more toxic than unburned coal because it contains higher concentrations of heavy metals and minerals (mercury, lead, arsenic, hexavalent chromium, cadmium, boron, and thallium).$^{25}$ The site at issue here is unlined and these contaminants can not only get into the local water sources but also blow in the air as "fugitive dust". "If eaten, drunk or inhaled, these toxicants can cause cancer and nervous system impacts such as cognitive deficits, developmental delays and behavioral problems." 27 "They can also cause heart damage, lung disease, respiratory distress, kidney disease, reproductive problems,

18. Pennsylvania Department of Corrections Monthly Population Report (Feb. 28, 2019), PA. DEP'T OF CORRECTIONS, https://www.cor.pa.gov/About\%20Us/Statistics/Documents/Current\% 20Monthly\%20Population.pdf [https://perma.cc/22YT-Z6CX].

19. SCI Fayette, PA. DeP'T OF CORRECTIONS, https://www.cor.pa.gov/Facilities/StatePrisons/ Pages/Fayette.aspx [https://perma.cc/3WHD-8YHZ].

20. Bernd, Mitra \& Loftus-Farren, supra note 16.

21. Id.

22. Id.

23. Id.

24. Id.

25. $I d$.

26. Id.

27. Coal Ash: Hazardous to Human Health, Physicians FOR Soc. ResP., https://www.psr. org/wp-content/uploads/2018/05/coal-ash-hazardous-to-human-health.pdf [https://perma.cc/XPL3FDRZ]. 
gastrointestinal illness, birth defects, and impaired bone growth in children." 28 Other health conditions that coal ash can cause or contribute to include "respiratory problems, hypertension, heart problems, brain and nervous system damage, liver damage, stomach and intestinal ulcers, and many forms of cancer, including skin, stomach, lung, urinary tract and kidney." ${ }^{29}$ Living near a coal ash disposal site can increase your risk of getting cancer and other diseases, according to the EPA. ${ }^{30}$

When the dumping started at the site, the residents of the nearby town of LaBelle began getting sick and reported respiratory problems, kidney failure, and cancers. ${ }^{31}$ They blamed the dumping site. ${ }^{32}$ Then, when SCI Fayette was built, inmates and staff began experiencing health problems similar to those of the local residents. $^{33}$

The Abolitionist Law Center and the Human Rights Coalition conducted a 12-month investigation into the health impacts of exposure to toxic coal waste on the inmates at Fayette. ${ }^{34}$ Their investigation found several troubling statistics among reporting inmates. ${ }^{35}$ For example, about " $81 \%$ of responding prisoners $(61 / 75)$ reported respiratory, throat, and sinus conditions, including shortness of breath, chronic coughing, sinus infections, lung infections, chronic obstructive pulmonary disease, extreme swelling of the throat, as well as sores, cysts, and tumors in the nose, mouth, and throat." ${ }^{36}$ Additionally, "68\% (51/75) of responding prisoners experienced gastrointestinal problems, including heart burn, stomach pains, diarrhea, ulcers, ulcerative colitis, bloody stools, and vomiting." ${ }^{37}$ Also, "52\% (39/75) reported experiencing adverse skin conditions, including painful rashes, hives, cysts, and abscesses." 38 Moreover, "12\% (9/75) of prisoners reported either being diagnosed with a thyroid disorder at SCI Fayette, or having existing thyroid problems exacerbated after transfer to the prison." ${ }^{.39}$ And finally, "[e]leven prisoners died from cancer at SCI Fayette between January of 2010 and December of 2013. Another six prisoners have reported being diagnosed with cancer at SCI Fayette and a further eight report undiagnosed tumors and lumps." ${ }^{40}$

\section{Id.}

29. Bernd, Mitra \& Loftus-Farren, supra note 16.

30. Coal Ash: Hazardous to Human Health, supra note 27.

31. Bernd, Mitra \& Loftus-Farren, supra note 16.

32. Id.

33. Id.

34. Dustin S. McDaniel, Bret Grote, Ben Fiorillo, Devon Cohen \& Quinn A. Cozzens, No Escape: Exposure to Toxic Coal Waste at State Correctional Institution FAYETTE (2014) 1, http://abolitionistlawcenter.org/wp-content/uploads/2014/09/no-escape-3-3mb. pdf [https://perma.cc/L67L-SK2L].

35. Id.

36. $I d$.

37. $I d$.

38. Id.

39. Id.

40. Id. at 2 . 
While one cannot definitively say that all of these prisoners experienced these conditions because of their exposure to coal ash, the statistics are alarming. ${ }^{41}$ The report asserts these prisoner's symptoms did not begin to appear until they arrived at Fayette - this is different from health reports from other Pennsylvania prisons. ${ }^{42}$ "The patterns of illnesses described in this report, coupled with the prison being geographically enveloped by a toxic coal waste site, point to a hidden health crisis impacting a captive and vulnerable population." 43

The report states that while they believe the inmates' health issues are caused by the toxic environment around the prison, "the inherent limitations of the survey do not establish this belief at an empirical level." ${ }^{44}$ The authors of the study understand that there will be more investigation needed to establish the connection between the inmates' health and exposure. ${ }^{45}$ The authors' understanding that there needs to be more research done to establish a relationship between the coal ash exposure and the inmates' declining health mirrors the big hurdle ligation will face in this arena - causation.

\section{B. Toxic Sludge-Northwest Detention Center (Washington)}

The Northwest Detention Center, located in Tacoma, Washington, holds undocumented immigrants and is located next to the Tacoma's Tar Pits. ${ }^{46}$ The Tar Pits are a Superfund site. ${ }^{47}$

Superfund is the informal name for the Comprehensive Environmental Response, Compensation and Liability Act (hereinafter "CERCLA"), which gives the EPA the authority to clean up contaminated sites. ${ }^{48}$ In addition, the act "forces the parties responsible for the contamination to either perform cleanups or reimburse the government for EPA-led cleanup work."49

The Tar Pits were once wetlands, however, that were filed in and used for industrial purposes. ${ }^{50}$ One such purpose was coal conversion, which produced

\section{Id. at 20 .}

42. Id. at 6 .

43. Id. at 2 .

44. Id.

45. Id.

46. Michael Waters, How Prisons are Poisoning their Inmates, The OutLine (July 23, 2018, 10:40 AM), https://theoutline.com/post/5410/toxic-prisons-fayette-tacoma-contaminated? $\mathrm{zd}=1 \& \mathrm{zi}=\mathrm{ya} 5 \mathrm{~d} 6 \mathrm{dym}[\mathrm{https}: / /$ perma.cc/4UPV-Z6KA].

47. Superfund Site Information: Tacoma Tar Pits, U.S. Envtl. Prot. Agency, https://cumulis.epa.gov/supercpad/cursites/csitinfo.cfm?id=1000965 [https://perma.cc/XBR678RN].

48. What is Superfund?, U.S. EnVtl. РRot. AgEnCy, https://www.epa.gov/superfund/whatsuperfund [https://perma.cc/3DV3-DMSA].

49. Id.

50. Dan McShane, The Grassy Knoll - Tacoma's, ReAding the Washington LANDSCAPE (May 13, 2010, 6:32 PM), https://washingtonlandscape.blogspot.com/2010/05/grassy-knoll- 
coal tar as waste. "The tar was disposed of by discharging it into the wetlands and other low areas around the site." 52

A Preliminary Final Environmental Impact Statement for the Tacoma/Seattle Detention Center found that the J Street location (what became the location of the Center), "contains undefined levels of hazardous waste contamination that exceeds established regulatory levels for both soil and groundwater." 53 This, along with the fact that the site is located abject to the Tar Pits led the report to say the site presented "an undefined risk associated with redevelopment of the site resulting in liability concerns." ${ }^{54}$ The report, therefore, selected a port site as the preferred alternative to the J Street location. ${ }^{55}$ However, port officials did not like this finding and turned to congressmen and other politicians to fight the decision. ${ }^{56}$ The "the agency ultimately changed its conclusions. Its final recommendation for a new Northwest detention facility did not identify a preferred building site, describing both as satisfactory for the project."

The newspaper who reported on this issue had three environmental attorneys analyze the review process, and all three said it was unusual in several ways. ${ }^{58}$ First, the lawyers pointed out that the state and federal studies were not synchronized, which normally happens. ${ }^{59}$

"Such coordination typically occurs partly because federal law requires that until a final decision on a federal environmental review has been made, "no action concerning the proposal shall be taken." ",60

Secondly, the Correctional Services Corporation "sought a separate state environmental determination ... only for one of the site alternatives in play- the East J Street site," and "[t]he city issued that determination several months before the federal decision had been made." ${ }^{\prime 1}$ And third, "the federal review's final impact statement did not identify a preferred site alternative as is usually required. Under federal law, a final environmental impact statement must identify the agency's preferred alternative, 'unless another law prohibits the expression of

tacomas.html [https://perma.cc/J43J-8WQY].

51. Id.

52. Id.

53. Immigration and Naturalization Serv., Preliminary Final Environmental Impact Statement for the Tacoma/Seattle Area Detention Center, Pierce County, WASHINGTON (Feb. 2001), http://www.documentcloud.org/documents/408887-snewsroomp12081312560.html\#document/p2/a67579 [https://perma.cc/43JL-4D42].

54. Id.

55. Id.

56. Lewis Kamb, A Rare Look Inside Tacoma's Northwest Detention Center, INVESTIGATEWEST (Sept. 9, 2012), http://www.invw.org/2012/09/09/a-rare-look-inside-tacoma1309/ [https://perma.cc/V6RP-Y6ZL].

57. $I d$.

58. Id.

59. Id.

60. Id.

61. Id. 
such a preference." "'62 The draft report had Taylor Way as the preferred building site, but "the final report stated federal bidding regulations "prohibit INS from identifying the preferred site prior to entering into a contract for the facility." "'63

The Center was built on the site despite warnings, ${ }^{64}$ and there are still health concerns at the Center-particularly about the water. ${ }^{65}$ This one example illustrates how economic and political pressure can cause a prison to be built on toxic land and result in an entire inmate population to get exposed to environmental hazards.

\section{Toxic Nuclear Waste-ADX Florence (Colorado)}

ADX Florence is the highest-security prison in the United States and is known for housing notorious inmates as well as inmates who are flight or behavior risks. ${ }^{66}$

The Cotter Uranium Mill is located a few miles away from Florence and once produced yellowcake; the Mill "produced and stored radioactive chemicals like uranium, vanadium, and molybdenum." tons of radioactive waste and much of that was stored in lined ponds - which are usually around 40 feet deep - meant to keep materials from leaking out." ${ }^{, 68}$

Waste from the Mill overflowed from "unlined impoundments" into a creek that flowed into the Arkansas River, which was a water source for nearby communities. ${ }^{69}$ A ditch was constructed in the 1970s to prevent the creek from flowing into the river, but it overflows during irrigation season. ${ }^{70}$ "Although the BOP expressed concerned in 1989 that the prison's water supply may have to be rerouted in the future due to pollution, a water quality report shows that the Arkansas still remained a source for the city's water supply as late as 2013." The EPA declared the Mill a Superfund site in 1984, stating that "waste from the mine had seeped into the groundwater and contaminated local wells." 72 Seventy leaks were reported between 1980 and 1986, and a State of Colorado

62. Id.

63. Id.

64. Id.

65. Id.

66. Mark Binelli, Inside America's Toughest Federal Prison, N.Y. Times (Mar. 26, 2015), https://www.nytimes.com/2015/03/29/magazine/inside-americas-toughest-federal-prison.html [https://perma.cc/6BYB-3N7C].

67. Waters, supra note 46.

68. Id.

69. Laura Cepero, Toxic Traps: Environmental Hazards Threaten Two Federal Supermax Prisons, SOLITARY WATch (Sept. 10, 2015), https://solitarywatch.org/2015/09/10/toxic-trapsenvironmental-hazards-threaten-two-federal-supermax-prisons/ [https://perma.cc/A9MU-HWCT].

70. Id.

71. Id.

72. Id. 
investigation "concluded that drainage from the Cotter mine spilled into the Fremont ditch, resulting in elevated levels of molybdenum, arsenic, lead, and other contaminants." 73 In addition, 19.9 tons of radioactive dust were released into the air every year the Mill was in operation, and because Florence lies in the Mill's wind pattern "the prison and its inhabitants are subject to gusts of radium, uranium, and thorium.".74

The Mill is still a Superfund site, "but the contamination concerns . . . appear to be dwindling thanks to cleanup efforts (the site isn't expected to lose Superfund status until at least 2027)," and "potential public exposures are below regulatory limits." ${ }^{.75}$ Nonetheless, inmates have spoken about their health issues and those they have observed in other inmates that they believe to be caused by exposure. $^{76}$

\section{Industrial Solvents and Nuclear Contamination- FCI Victorville (California)}

Victorville Federal Correctional Complex consists of three facilities and houses thousands of inmates in San Bernardino County. ${ }^{77}$ It is built on what was once George Air Force Base. ${ }^{78}$ The Base closed in 1992 and opened in 1941 just before the United States joined the fight in World War II. ${ }^{79}$ There were reports of soil contamination on base in 1977 which included pesticide contamination near base housing. ${ }^{80}$ By 1981 medical personnel were advising women not to get pregnant while being stationed at the base because of the high infant mortality rate. ${ }^{81}$ In the $1980 \mathrm{~s}$ the Air Force acknowledged contamination by jet fuel, gasoline, paints, and solvents. ${ }^{82}$ The Air Force initially denied any nuclear waste testing at the Base, however, it has since become clear that there was nuclear and other radioactive work done on the Base, and that radioactive materials were disposed of there. ${ }^{83}$ In 1979, environmental tests done by the U.S. Air Force

73. Id.

74. Id.

75. Waters, supra note 46.

76. $I d$.

77. FCI Victorville Medium II, FED. BuREAU OF PRISONS, https://www.bop.gov/locations/ institutions/vvm/ [https://perma.cc/2688-MT66]; FCI Victorville Medium I, FED. BuREAU OF PRISONS, https://www.bop.gov/locations/institutions/vim/ [https://perma.cc/AM8W-C9GX]; USP Victorville, FED. BUREAU OF PRISONS, https://www.bop.gov/locations/institutions/vip/ [https:// perma.cc/9328-QJ3T].

78. Waters, supra note 46.

79. Mark Gutglueck, Air Force Less Than Clear on Extent of Nuclear Contamination at GAFB, SAN BERnARdino County Sentinel (May 17, 2015), http://sbcsentinel.com/2015/05/airforce-less-than-clear-on-extent-of-nuclear-contamination-at-gafb/ [https://perma.cc/XRP3-5ETQ].

80. Id.

81. Id.

82. Id.

83. Id. 
found " 18 to 2055 -gallon drums of radioactive material...had been dumped at the site." $" 84$

In 2016 the California Water Boards requested soil sampling be done at school sites now on the former Base. ${ }^{85}$ The Boards were concerned about pesticide contamination because pesticides had been applied at the former housing area beneath and around the building foundations for terminate control purposes. ${ }^{86}$ One of the pesticides used was Dieldrin, "a toxic chlorinated pesticide that is relatively persistent and immobile," and was banned in the United States by 1987; it can "cause adverse health effects when present at high concentrations." "Dieldrin has been linked to human health problems including Parkinson's disease and breast cancer, and damage to the immune, reproductive, and nervous systems. $"{ }^{88}$

Several service members who were stationed at the Base think radioactive waste caused their health problems. ${ }^{89}$ For example, Kenn Finkelstein was stationed at the base and said "he developed hundreds of warts on his feet before later losing a kidney to cancer." ${ }^{90}$ Furthermore, he was "discharged for health reasons in 1974 after suffering seizures, migraines, and excessive bleeding because of radiation exposure." ${ }^{.11}$ Another example of health problems at the base is illustrated by the fact that women there were warned not to get pregnant during the 1990s due to "disproportionate numbers of hysterectomies, miscarriages, and babies born with birth defects." 92

FCI Victorville was built twelve years after the base closed down. ${ }^{93}$ The EPA is letting the toxic water degrade on its own rather than clean it up as part of its policy of monitored natural attenuation. ${ }^{94}$ The California Water Boards found that this waiting policy means it will take over 500 years for the water to be restored. ${ }^{95}$

Several prisoners blame the contaminated water for their health concerns. ${ }^{96}$ After Eric McDavid was released, he found elevated levels of copper in his

84. Waters, supra note 46.

85. Cal. Water Bds, Request for Soll Sampling at the School Properties, NonCercla Site Ot071, Former George Air Force Base, Victorville, San Bernardino COUNTY (April 8, 2016) 1, https://truthout.org/wp-content/uploads/legacy/documents/2016_0417soil-sampling-at-schools.pdf [https://perma.cc/WZK4-T3G4].

86. Id.

87. Id. at 1-2.

88. Id. at 2 .

89. Waters, supra note 46.

90. Id.

91. Id.

92. Id.

93. Id.

94. Id.

95. Id.

96. Id. 
system. ${ }^{97}$ He says the copper levels were "40 times higher than what it should have been." ${ }^{.98}$ Pauline Blake was detained in Victorville from 2011 to 2016 and said that the inmates were told to only drink water and that it sometimes was "a grayish-brown," after it went through a filter. ${ }^{99}$ Blake said the guards would not drink the water. ${ }^{100}$ Blake also said the prison "saw an outbreak of stomach ulcers caused by the bacterium H. pylori.",101

\section{E. Indianapolis's New Criminal Justice Center}

The city of Indianapolis broke ground on a new criminal justice center in July of 2018. ${ }^{102}$ The new center is being constructed on the former Citizens Energy coke plant and is scheduled to be completed in 2021. ${ }^{103}$ The site "will undergo environmental remediation with the Indiana Department of Environmental Management and experts from Purdue University." ${ }^{104}$ Construction of the center will begin once the site remediation is completed, but before water quality is restored. ${ }^{105}$ Jeffrey Harrison, CEO of Citizens Energy Group said "the long-term goal is that the water quality of the site will be restored by 2025." "The City is leasing the contaminated land for the time being and will take full ownership Citizens completes its remediation work. ${ }^{107}$

"Coke is a fuel and reducing agent in melting iron ore." ${ }^{108}$ Citizens produced coke on the site for 99 years. ${ }^{109}$ The plant closed in 2007, but the land and creek

97. Id.

98. Id.

99. Id.

100. $I d$.

101. Id.

102. Indianapolis Breaks Ground on Robust New Criminal Justice Center, CORRECTIONAL News (July 19, 2018), http://correctionalnews.com/2018/07/19/indianapolis-breaks-ground-robustnew-criminal-justice-center/ [https://perma.cc/35X6-VLLR].

103. Id.

104. Fatima Hussein, Indianapolis Takes Next Step Toward Long-Sought New Criminal Justice Center, INDYSTAR (Dec. 18, 2017), https://www.indystar.com/story/news/2017/12/18/indianapolistakes-next-step-toward-long-sought-new-criminal-justice-center/960590001/ [https://perma.cc/MGR4-BUK6].

105. Id.

106. Id.

107. Id.

108. How Does Coke and Coal Play Into Steel Making?, Fed. Steel Supply, Inc. (June 22, 2016), https://www.fedsteel.com/our-blog/how-does-coke-and-coal-play-into-steel-making/ [https://perma.cc/3HGC-4FG7].

109. Russ McQuaid, \$24 Million In Cleanup Continues at Proposed Site for New Criminal Justice Complex, Fox59 (Feb. 7, 2017, 9:05 AM), https://fox59.com/2017/02/07/24-million-incleanup-continues-at-proposed-site-for-new-criminal-justice-complex/ [https://perma.cc/PE6ZHGSW]. 
bed on the site were polluted from coal tar deposits. ${ }^{110}$ "Coal tar is derived from coal. It is a byproduct of the production of coke... and coal gas. Coal tar is used primarily for the production of refined chemicals and coal-tar products, such as creosote and coal-tar pitch." ${ }^{111}$ Coal tar can be a carcinogen in heavy concentrations. ${ }^{112}$

Citizens has been cleaning up the site for a decade and has spent $\$ 12$ million "on environmental studies as well as some environmental remediation work." 113 When the cleanup first started Citizens stated that their studies indicated that the "contamination is contained on the site and therefore, does not pose a danger to public health as defined by the U.S. Environmental Protection Agency." 114 Citizens said they were focused on protecting a waterway "from potential effects from the plant site." 115 The waterway is "impacted by a variety of sources of pollution, including overflows from the aging sewer system that Citizens acquired in 2011." "116 Citizens states they will complete "an underground tunnel system that will virtually eliminate sewer overflows" in waterways over the next 11 years. ${ }^{117}$

A corporate communications manager for Citizens "said coal tar deposits on the land are inert and don't migrate but have settled into the bed of [the waterway], which runs through the land" 118 The manager also said they found some coal tar deposits in the sediments and mud of the creek. ${ }^{19}$ According to the manager, Citizens planned to start removing these deposits in the summer of 2017. ${ }^{120}$ The manager also said while there were "some impacts to the shallow groundwater" there were no impacts to the deep ground. ${ }^{121}$ The manager at Citizens said the coal tar at the site for the new justice center is:

Not a threat to human health ... In some cases, the coal tar deposits will be removed. In other cases, they will be left in place because they pose no threat to human health or the environment, so they'll be paved over. "In areas where there's buildings there will be appropriate measures of

110. Id.

111. Coal Tar and Coal-Tar Pitch, NAT'L CANCER INST., https://www.cancer.gov/aboutcancer/causes-prevention/risk/substances/coal-tar [https:/perma.cc/7CY7-XJTB] (last updated Dec. 28, 2018).

112. McQuaid, supra note 109.

113. Id.

114. Jeff Harrison, Citizens Energy Working to Clean Up Old Coke Plant Site, INDYSTAR (May 16, 2014, 4:10 PM), https://www.indystar.com/story/opinion/readers/2014/05/16/citizensenergy-working-clean-old-coke-plant-site/9184973/ [https://perma.cc/39SK-JPL5].

115. Id.

116. Id.

117. Id.

118. McQuaid, supra note 109.

119. Id.

120. Id.

121. Id. 
remediation taken to accommodate those buildings and in other areas where there's parking lots, there'll be another level of remediation. ${ }^{122}$

The site was chosen because of its "size, location, access to main streets, proximity to criminal justice challenges and acceptance of neighbors."

The new criminal justice center has been pitched as a win for the community. Mayor Hogsett said:

For nearly a century in the Twin Aire neighborhood, the former Citizens Energy Coke Plant helped fuel the steel industry. But since operations ceased in 2007, that land has stood vacant and the neighborhood has yearned for community development and investment. Today is a testament to the community members and neighborhood leaders who tirelessly advocated for the Community Justice Campus in Twin Aire. ${ }^{124}$

However, building a new prison on such a contaminated site should cause our community to pause. Yes, a new, not overcrowded prison is good. Yes, bringing new jobs to an area that lost so many when a factory left the neighborhood is good. However, these are these were the same promises made when prisons were built in coal country. ${ }^{125}$ And as a community Indianapolis needs to not only hold the Citizens accountable for the pollution they caused to the neighborhood but also the community needs to hold the city of Indianapolis responsible before they house 3,000 inmates on land that could potentially cause them health problems in the future. ${ }^{126}$

\section{THE UNCONSTITUTIONALITY OF TOXIC PRISONS}

Forcing inmates to live on toxic land is unconstitutional not only an environmental justice concern since it disproportionately affects minorities and low-income individuals, but it is also unconstitutional. ${ }^{127}$ These exposures are unconstitutional in two ways - first as a substantive due process violation under the fourteenth amendment, and second as a form of cruel and unusual punishment under the eighth amendment. ${ }^{128}$ It is a substantive due process violation because by building prisons on or near toxic land sites the government created a danger

122. Id.

123. Id.

124. Jordan Fischer \& Rafael Sanchez, Mayor Hogsett announces Old Citizens Energy coke plant to be site of new Community Justice Campus, RTV6 INDIANPOLIS (Jan. 30, 2017, 1:21 $\mathrm{PM}$ ), https://www.theindychannel.com/news/crime/call-6-old-citizens-energy-coke-plant-to-be-siteof-new-criminal-justice-complex [https://perma.cc/5LHU-BHP8].

125. See Nicole Greenfield, The Connection Between Mass Incarceration and Environmental Justice, NRDC (Jan. 19, 2018) https://www.nrdc.org/onearth/connection-between-massincarceration-and-environmental-justice [https://perma.cc/27LG-EVJ3].

126. See Indianapolis Breaks Ground on Robust New Criminal Justice Center, supra note 102.

127. See Sakala, supra note 6.

128. See U.S. CONST. amend. XIV; U.S. Const. amend. VIII. 
that harmed the inmates - this, therefore, meets the danger creation exception. ${ }^{129}$ Secondly, by being deliberately indifferent to the serious medical needs of the inmates these the government engaged in cruel and unusual punishment. ${ }^{130}$

\section{A. Substantive Due Process Violation}

The exposures at issue here are substantive due process violations and are therefore unconstitutional under the fourteenth amendment.

Generally, the due process clause does not require the government to act to protect due process rights. ${ }^{131}$ However, the "danger creation exception" allows a substantive due process claim when the government "places a person in peril in deliberate indifference to their safety." 132 Several circuits have recognized the danger creation exception. ${ }^{133}$ However, the elements for what meets this exception varies from circuit to circuit. ${ }^{134}$

For example, in the Ninth Circuit, a plaintiff must prove the "state action create[d] or expose[d] an individual to a danger which he or she would not have otherwise faced." 135 Additionally, "the state action must place the plaintiff "in a worse position than that in which he would have been had the state not acted at all." 136 Furthermore, the plaintiff must also prove the "state actor . . . recognize[d] the unreasonable risks to the plaintiff and 'actually intend[ed] to expose the plaintiff to such risks without regard to the consequences to the plaintiff." "137 Lastly, the state actor had to act with "[d]eliberate indifference," which "requires a culpable mental state more than gross negligence."138 In contrast, the Third Circuit's elements for the danger creation exception are:

(1) "the harm ultimately caused was foreseeable and fairly direct;" (2) a state actor acted with a degree of culpability that shocks the conscience;

129. See Penilla v. City of Huntington Park, 115 F.3d 707, 709-10 (9th Cir. 1997).

130. Estelle v. Gamble, 429 U.S. 97, 104 (1976).

131. DeShaney v. Winnebago County Dep. of Social Services, 489 U.S. 189, 196 (1989).

132. Penilla, 115 F.3d at 709.

133. See Cornelius v. Town of Highland Lake, 880 F.2d 348, 356 (11th Cir. 1989); Kneipp v. Tedder, 95 F.3d 1199, 1208-1211 (3d Cir. 1996); Dwares v. City of New York, 985 F.2d 94, 99 (2d Cir. 1993); Reed v. Gardner, 986 F.2d 1122, 1124-25 (7th Cir. 1993); Freeman v. Ferguson, 911 F.2d 52, 54-55 (8th Cir. 1990).

134. See Bright v. Westmoreland County, 443 F.3d 276, 281 (3d Cir. 2006); Juliana v. United States, 217 F. Supp. 3d 1224, 1251 (D. Or. 2016).

135. Kennedy v. City of Ridgefield, 439 F.3d 1055, 1061 (9th Cir. 2006).

136. Juliana, 217 F. Supp. 3d at 1251 (quoting Pauluk v. Savage, 836 F.3d 1117, 1125 (9th Cir. 2016)).

137. Id. (quoting Campbell v. Wash. Dep't of Soc. \& Health Servs., 671 F.3d 837, 846 (9th Cir. 2011)).

138. Pauluk v. Savage, 836 F.3d 1117, 1125 (9th Cir. 2016) (quoting Patel v. Kent Sch. Dist., 648 F.3d 965, 974 (9th Cir. 2011). 
(3) a relationship between the state and the plaintiff existed such that "the plaintiff was a foreseeable victim of the defendant's acts," or a "member of a discrete class of persons subjected to the potential harm brought about by the state's actions," as opposed to a member of the public in general; and (4) a state actor affirmatively used his or her authority in a way that created a danger to the citizen or that rendered the citizen more vulnerable to danger than had the state not acted at all. ${ }^{139}$

While some of these elements are similar, the Third Circuit has more elements, and those elements impose a higher standard than the Ninth Circuit. ${ }^{140}$ Therefore, this note will illustrate that the inmates' claims would meet this higher standard and will examine the claims that would result from the exposures at FCI Victorville in particular.

\section{Reasonably Foreseeable}

The first element "the harm ultimately caused was foreseeable and fairly direct." ${ }^{141}$ In Kneipp v. Tedder, the Third Circuit held that the injuries to the plaintiff were foreseeable. ${ }^{142}$ There, Samantha Kneipp her husband Joseph were returning on foot from a night of drinking, and according to Joseph, "Samantha was visibly intoxicated - she smelled of urine, staggered when she walked and, at times, was unable to walk without assistance." ${ }^{\prime 43}$ A police officer stopped the Kniepps, and Samantha was leaning on the officer's car because she was unable to stand by herself. ${ }^{144}$ Joseph left at one point to check on the couple's children that were with a babysitter and left to walk home, leaving Samantha behind. ${ }^{145} \mathrm{He}$ thought the officers were going to take Samantha either the hospital or to the police station; "his thoughts at the time were that Samantha should not be left alone in her inebriated state and that the police officers would take care of her, so he proceeded home without her." ${ }^{146}$ However, the officer sent her home alone and she never made it. ${ }^{147}$ Later that night Samantha "was found unconscious at the bottom of an embankment next to a parking lot at the shopping plaza across the

139. Bright, F.3d at 281 (quoting Kneipp v. Tedder, 95 F.3d 1199, 1208 (3d Cir. 1996); citing County of Sacramento v. Lewis, 523 U.S. 833, 118 S. Ct. 1708, 140 L. Ed. 2d 1043 (1998); Miller v. City of Philadelphia, 174 F.3d 368, 375-76 (1999); Schieber v. City of Philadelphia, 320 F.3d 409, 416 (2003); quoting Morse v. Lower Merion Sch. Dist., 132 F.3d 902, 906, 913 (3d Cir. 1997); citing Rivas v. City of Passaic, 365 F.3d 181, 195 (3d Cir. 2004); Deshaney v. Winnebago County Dep't of Social Services, 489 U.S. 189, 201 (1989)).

140. See generally Juliana, F. Supp. 3d at 1251; Bright, 443 F.3d at 281.

141. Bright, 443 F.3d at 281 (quoting Kneipp v. Tedder, 95 F.3d 1199, 1208 (3d Cir.1996)).

142. Kneipp v. Tedder, 95 F.3d 1199, 1208 (3d Cir.1996).

143. Id. at 1201.

144. Id.

145. Id. at 1202 .

146. Id.

147. Id. 
street from" her home. ${ }^{148}$ "As a result of her exposure to the cold, Samantha suffered hypothermia, which caused a condition known as anoxia. Consequently, the anoxia resulted in permanent brain damage impairing many basic body functions." 149

The court reasoned Samantha's injuries were reasonably foreseeable because an expert reported that at her high blood alcohol level of .25\%, her muscular coordination would have been "seriously impaired." 150 Additionally, the court said Joseph's testimony about having to help his wife walk showed her inability to walk. ${ }^{151}$ The court held Samantha's injuries were foreseeable because "[a] reasonable trier of fact could conclude that in Samantha's state of intoxication, she would be more likely to fall and injure herself if left unescorted than someone who was not inebriated." 152

Here it was reasonably foreseeable that the exposure to the toxins would cause injuries to the plaintiff because the government knew of and acknowledged the contamination on the land before the prison was built. ${ }^{153}$ For example, in 1979 about twenty drums of radioactive material were to have been dumped at the site. ${ }^{154}$ These drums were found "a quarter mile upstream of the wells used" at the base, and some believe the radioactive waste trickled directly into these wells because "[t]he groundwater flows northeast from the [radioactive dumping site], directly toward" the wells. ${ }^{155}$ The fact that the government knew about the contamination means that the harm was foreseeable because when one is aware of contamination it is reasonable to conclude that it might harm people, especially here because they also knew of the health problems associated with the contamination. ${ }^{156}$ This is evidenced by the fact that by 1981 , medical personnel were advising women not to get pregnant while being stationed at the base because of the high infant mortality rate. ${ }^{157}$ Because the government knew of the contamination and knew it could cause health problems, the harm caused was foreseeable.

\section{Shocks-the-Conscience Test}

The second element is that the "state actor acted with a degree of culpability that shocks the conscience." 158 Courts have found behavior like the forced

148. Id

149. Id. at 1203 .

150. Id. at 1208 .

151. Id.

152. Id.

153. Gutglueck, supra note 79.

154. Waters, supra note 46.

155. Id.

156. Id.

157. Gutglueck, supra note 79.

158. Bright v. Westmoreland County, 443 F.3d 276, 281 (3d Cir. 2006) (citing County of 
pumping of an inmate's stomach to shock the conscience. ${ }^{159}$ Additionally, the Supreme Court said in County of Sacramento v. Lewis that actions constituting deliberate indifference can shock the conscience in certain circumstances. ${ }^{160}$ However, this is a fact-sensitive determination; the court in Lewis said "[d]eliberate indifference that shocks in one environment may not be so patently egregious in another, and our concern with preserving the constitutional proportions of substantive due process demands an exact analysis of circumstances before any abuse of power is condemned as conscienceshocking." 161 There, the Court held that a high-speed chase with "no intent to harm suspects physically or to worsen their legal plight" does not shock the conscience and does not violate the Fourteenth Amendment. ${ }^{162}$ Nonetheless, they said deliberate indifference could be conscience shocking in custodial settings. ${ }^{163}$ They reasoned that this is because when the State takes someone into custody there is a constitutional duty to provide for their safety and well-being. ${ }^{164}$ "The rationale for this principle is simple enough: when the State by the affirmative exercise of its power so restrains an individual's liberty that it renders him unable to care for himself, and at the same time fails to provide for his basic human needs . . . it transgresses the substantive limits on state action set by the . . . Due Process Clause." 165 The court considers the difference between in-custody and out-of-custody actions by police. ${ }^{166}$ They reasoned that prison officials have "time to make unhurried judgments, upon the chance for repeated reflection, largely uncomplicated by the pulls of competing obligations. When such extended opportunities to do better are teamed with protracted failure even to care, indifference is truly shocking." 167 The court then contrasts this to circumstances involving police in non-custody situations, stating "when unforeseen circumstances demand an officer's instant judgment, even precipitate recklessness fails to inch close enough to harmful purpose to spark the shock that implicates 'the large concerns of the governors and the governed."'168 An Eighth Circuit case succinctly states when using deliberate indifference for the shocks-the-conscience test is appropriate. "In cases where "defendants acted under circumstances in

Sacramento v. Lewis, 523 U.S. 833, 118 S. Ct. 1708, 140 L. Ed. 2d 1043 (1998); Miller v. City of Philadelphia, 174 F.3d 368, 375-76 (1999); Schieber v. City of Philadelphia, 320 F.3d 409, 416 (2003)).

159. Cty. Of Sacramento v. Lewis, 523 U.S. 833, 846 (1998) (citing Rochin v. California, 342 U.S. 165, 172-73 (1952)).

160. Id. at 850 .

161. Id.

162. Id. at 854 .

163. Id. at 851

164. Id..

165. Id. (quoting DeShaney v. Winnebago County Dept. of Social Servs., 489 U.S. 189, 199200 (1989).

166. Id. at 851-53.

167. Id at 853 .

168. Id. at 848 (quoting Daniels v. Williams, 474, U.S. 327, 332 (1986)). 
which actual deliberation was practical ... their conduct may shock the conscience of federal judges only if they acted with "deliberate indifference."'169

Here, because the inmates are in custody and actual deliberation was practiced, it is appropriate to analyze the conscience-shocking element through a deliberate indifference lens. The deliberate indifference standard applied in a substantive due process case is the same as that applied in Eighth Amendment cases. ${ }^{170}$ Once again, the circuits' standards for deliberate indifference vary slightly. ${ }^{171}$ For example, in the Eighth Circuit for deliberate indifference, "the official must both be aware of facts from which the inference could be drawn that a substantial risk of serious harm exists, and he must also draw the inference."172 In contrast, the Eleventh Circuit held "deliberate indifference has three components: (1) subjective knowledge of a risk of serious harm; (2) disregard of that risk; (3) by conduct that is more than mere negligence." ${ }^{173}$ This note will explore the Eleventh Circuit's elements in a later section analyzing the cruel and unusual punishment claim. So, here the note will examine deliberate indifference using the Eighth Circuit's elements to demonstrate how these inmates' claims will be successful regardless of where the claims are brought.

Here the officials were "both . . . aware of facts from which the inference could be drawn that a substantial risk of serious harm exists," and drew the inference. ${ }^{174}$ As stated previously, the government knew of and acknowledged the contamination on the land before the prison was built - this means that they were aware of the facts from which the inference could be drawn. Furthermore, the government has been slowly attempting to clean up the site for twenty years, which is also evidence that they were aware of the contamination. ${ }^{175}$ Additionally, they knew "trichloroethylene, a cancer-causing solvent, has contaminated two aquifers underneath the base and threatens a third aquifer, as well as the Mojave River. It has also tainted monitoring wells at a nearby wastewater reclamation plant and forced workers there to drink bottled water as a precaution."176 Furthermore, the fact that as far back as 1981, medical personnel were advising women not to get pregnant while being stationed at the base because of the high

169. Moore ex rel. Moore v. Briggs, 381 F.3d 771, 773 (8th Cir. 2004) (citing Cty. of Sacramento v. Lewis, 523 U.S. 833, 851-52 (1998)).

170. Estate of Johnson v. Weber, 785 F.3d 267, 272 (8th Cir. 2015).

171. See generally McElligott v. Foley, 182 F.3d 1248, 1255 (11 th Cir. 1999); see also Estate of Johnson, 785 F.3d at 272.

172. Estate of Johnson, 785 F.3d at 272 (citing Moore ex rel. Moore v. Briggs, 381 F.3d 771, 773-74 (8th Cir. 2004)).

173. McElligott, 182 F.3d at 1255.

174. Estate of Johnson, 785 F.3d at 272 (citing Moore ex rel. Moore v. Briggs, 381 F.3d 771, 773-74 (8th Cir. 2004).

175. Dan Ross, Why the EPA Is Allowing Contaminated Groundwater to Go Untreated, NEwSWEEK (Mar. 9, 2017), https://www.newsweek.com/2017/03/17/toxic-waste-contaminatedwater-monitored-natural-attenuation-epa-565830.html [https://perma.cc/6BNA-HDJH].

176. Id. 
infant mortality rate is evidence that officials drew the inference that the contamination could cause health concerns. ${ }^{177}$

Because the officials were aware of the contamination and of the health concerns associated with that contamination, they were deliberately indifferent to the plight of the men that would be housed there. This meets the shocks-theconscience test not only because these individuals are in custody, but also because the "defendants acted under circumstances in which actual deliberation was practical." 178 The governmental officials could have built the prison someone else, but they decided to put in on contaminated land with contaminated groundwater - they decided it was okay to force people to live on land that could kill them and that should shock one's conscience.

\section{Relationship Between the State and Plaintiff}

The third element of the danger creation exception is "a relationship between the state and the plaintiff existed such that 'the plaintiff was a foreseeable victim of the defendant's acts,' or a 'member of a discrete class of persons subjected to the potential harm brought about by the state's actions,' as opposed to a member of the public in general." "179 In Kneipp, the court held that there was "a relationship between the state and the person injured" because "[a] reasonable jury could find that [the] [o]fficer exerted sufficient control over Samantha to meet the relationship requirement." ${ }^{\text {180 }}$ However, there was no real dispute as to whether or not a relationship existed. ${ }^{181}$ Therefore, in Morse v. Lower Merion School Dis. the lower court examined the pre-Kneipp decisions to understand the parameters of this requirement. ${ }^{182}$ The lower court analyzed Doe v. Methacton Sch. Dist. "which held that the state-created danger theory would only affix liability if the victim of the resulting harm is 'known and identified,' and not 'simply a member of the greater public.","183

Here, at FCI Victorville for example, the inmates were not only a "foreseeable victim of the defendant's acts," but they were also a "discrete class of persons." " When the Federal Bureau of Prisons decided to build the complex in southern California the foreseeable victims were those inmates who were going to be forced to live on the land. Additionally, the inmates are a discrete class of persons and not members of the greater public because they were "known and identified"- they were inmates who were going to be sent to serve their time at

177. Gutglueck, supra note 79.

178. Moore ex rel. Moore, 381 F.3d at 773.

179. Bright v. Westmoreland Cty., 443 F.3d 276, 281 (quoting Kneipp v. Tedder, 95 F.3d 1199, 1209 (3d Cir. 1996); Morse v. Lower Merion Sch. Dis., 132 F.3d 902, 905-06 (3d Cir. 1997)).

180. Kneipp v. Tedder, 95 F.3d 1199, 1209 (3d Cir. 1996).

181. Morse v. Lower Merion Sch. Dis., 132 F.3d 902, 906 (3d Cir. 1997)).

182. Id.

183. Id. (quoting Doe v. Methacton Sch. Dist., 880 F. Supp. 380, 386 (E.D. Pa. 1995)).

184. See Bright, 443 F.3d at 281. 
FCI Victorville, not just members of the "greater public" who might happen to live on the contaminated land. ${ }^{185}$

\section{State Actor Affirmatively Used Their Authority to Create a Danger}

The fourth and final element of the danger creation exception is that "a state actor affirmatively used his or her authority in a way that created a danger to the citizen or that rendered the citizen more vulnerable to danger than had the state not acted at all." 186 There, the Court explained, "while we have acknowledged that the line between action and inaction may not always be clear . . . we have never found a state-created danger claim to be meritorious without an allegation and subsequent showing that state authority was affirmatively exercised." ${ }^{187}$ In Kneipp for example, the court held that there was sufficient evidence to show that the officers "used their authority as police officers to create a dangerous situation or to make Samantha more vulnerable to danger had they not intervened." 188 The court reasoned that by letting Joseph go home alone and by keeping Samantha before then letting her go "in a seriously intoxicated state in cold weather, made Samantha more vulnerable to harm. It is conceivable that, but for the intervention of the police, Joseph would have continued to escort his wife back to their apartment where she would have been safe."189

Here, the state "affirmatively used" its "authority in a way that created a danger" to the inmates by building a prison on toxic land. ${ }^{190}$ Building a prison is an affirmative action. Additionally, building it on contaminated land and is affirmative action taken by the government that created a danger. The second way this element can be met, and how it was met in Kneipp, is when the state "rendered the citizen more vulnerable to danger than had the state not acted at all." " ${ }^{191}$ Here, the inmates' claims met this option for the fourth element as well because had the government not acted by not building the prison the inmates would have been less vulnerable to the danger of exposure.

The inmates of FCI Victorville claims to due process violation meet the danger creation exception because (1) the harm to the inmates was foreseeable, (2) the government's actions met the shocks-the-conscience test, (3) the inmates were the foreseeable victims of the government's actions and (4) the government affirmatively used their authority to create the danger. ${ }^{192}$ For these reasons the

185. See Morse, 132 F.3d at 906.

186. Bright, 443 F.3d at 281.

187. Id. at 282 .

188. Kneipp v. Tedder, 95 F.3d 1199, 1209 (3d Cir. 1996).

189. Id.

190. See Bright, 443 F.3d at 281.

191. Bright, 443 F.3d at 281; Kneipp, 95 F.3d at 1209.

192. See Bright, F.3d at 281 (quoting Kneipp v. Tedder, 95 F.3d 1199, 1208 (3d Cir. 1996); citing County of Sacramento v. Lewis, 523 U.S. 833, 118 S. Ct. 1708, 140 L. Ed. 2d 1043 (1998); Miller v. City of Philadelphia, 174 F.3d 368, 375-76 (1999); Schieber v. City of Philadelphia, 320 
toxic exposures discussed in this note are a substantive due process violation and are therefore unconstitutional.

\section{B. Cruel and Unusual Punishment}

In addition to being a due process violation, these toxic prisons are also a form of cruel and unusual punishment and are therefore unconstitutional under the Eighth Amendment. The Eighth Amendment is violated when there is deliberate indifference to an inmate's serious medical needs. ${ }^{193}$ "To prevail on this type of claim a plaintiff must show (1) a serious medical need; (2) deliberate indifference to that need on the part of the defendant; and (3) causation between the defendant's indifference and the plaintiff's injury." 194

In Clemmons v. Bohannon the inmate plaintiff Clemmons was a nonsmoker at the Kansas State Penitentiary. ${ }^{195} \mathrm{He}$ alleged being involuntarily exposed to environmental tobacco smoke (hereinafter "ETS") violated his Eighth Amendment right to be free from cruel and unusual punishment. ${ }^{196}$ The court held that exposure to ETS did not rise to an Eighth Amendment violation because there was no evidence that Clemmons' health was adversely affected by the cigarette smoke. ${ }^{197}$ Additionally, Clemmons did not demonstrate that the defendants were deliberately indifferent to serious medical needs. ${ }^{198}$

On the first issue of serious medical need, Clemmons submitted affidavits about his exposure to ETS. ${ }^{199}$ Clemmons claimed he suffered from

physical problems and medical problems as a result of . . inhal[ing] carcinogens from the tobacco of inmates who smoke tobacco" on a "daily basis" and expose him to "toxic smoke fumes" and "stress." Clemmons alleges that he "suffers shortness of breath." Clemmons's pro se brief opposing summary judgment, signed but not sworn, states that his "throat, eyes and nose" were irritated by tobacco smoke and that this irritation required repeated medical care. ${ }^{200}$

The court reasoned that even if there were sufficient facts proving his injuries were linked to ETS, "these symptoms alone do not compare to the medical needs that courts have found sufficiently serious to constitute an Eighth Amendment

F.3d 409, 416 (2003); quoting Morse v. Lower Merion Sch. Dist., 132 F.3d 902, 906, 913 (3d Cir. 1997); citing Rivas v. City of Passaic, 365 F.3d 181, 195 (3d Cir. 2004); Deshaney v. Winnebago County Dep't of Social Services, 489 U.S. 189, 201 (1989)).

193. Estelle v. Gamble, 429 U.S. 97, 104 (1976).

194. Mann v. Taser Intern, Inc., 588 F.3d 1291, 1306-07 (11th Cir. 2009).

195. Clemmons v. Bohannon, 956 F.2d 1523, 1524 (10th Cir. 1992).

196. Id.

197. Id. at 1525 .

198. Id.

199. Id. at 1526.

200. Id. 
violation." ${ }^{201}$ The court cited several cases where the medical need did rise to an Eighth Amendment violation, and those medical needs were much more severe - for example, a "painful nasal deformity requiring surgery and head injury from being struck with a lead pipe may be sufficiently serious;" 202 "gross medical deficiencies in prison resulting in undiagnosed tuberculosis, untreated broken back, and unattended abscessed rectum sufficiently serious," 203 and "deep, heavily bleeding eye injury requiring stitches sufficiently serious." 204

On the second requirement that the defendants were deliberately indifferent to the medical need, the court reasoned:

Even if we concede that exposure to ETS can have serious medical consequences, the allegation of exposure in a penitentiary setting, without more, is not enough to satisfy the subjective component of cruel and unusual punishment. If plaintiff had shown or even alleged that defendants forced him to live with others who smoked and that they did so intentionally, knowing the smoke would have serious medical consequences for him, a different result might obtain. Indeed, constant confinement under those conditions could be patently cruel. Yet, defendants consistently made a reasonable effort to accommodate plaintiff's needs consistent with the conditions found in the institution. ${ }^{205}$

So, Clemmons's exposure to ETS was not a sufficient medical need and there was no deliberate indifference to his exposure, and therefore he did not meet the necessary elements for an Eighth Amendment claim. ${ }^{206}$ However, his case provides a good example of an exposure cause brought as an Eighth Amendment claim. And the cases discussed above have stronger claims than Clemmons'.

\section{Serious Medical Need}

Courts have defined a serious medical need as "one that has been diagnosed by a physician as mandating treatment or one that is so obvious that even a lay person would easily recognize the necessity for a doctor's attention."207 Additionally, "whether a delay in treating the need worsens the condition" is another way of determining a serious medical need. ${ }^{208}$ "In either case, "the medical need must be one that, if left unattended, poses a substantial risk of serious harm."'209

201. Id.

202. Id. (citing Dace v. Solem, 858 F.2d 385, 386-88 (8th Cir. 1988)).

203. Id. (citing French v. Owens, 777 F.2d 1250, 1254 (7th Cir. 1985)).

204. Id. (citing Aldridge v. Montgomery, 753 F.2d 970, 972 (11th Cir. 1985)).

205. Id. at 1528 .

206. Id. at 1526 .

207. Hill v. Dekalb Reg'l Youth Det. Ctr., 40 F.3d 1176, 1187 (11th Cir. 1994).

208. Id. at 1188-1189.

209. Mann v. Taser Intern, Inc., 588 F.3d 1291, 1307 (11th Cir. 2009) (quoting Farrow v. 
For example, a severe cataract that resulted in blindness in one eye was deemed to be a serious medical need. ${ }^{210}$ Additionally, a delay in an inmate's treatment for dentures was found to be a serious medical need because the evidence illustrated "pain, continual bleeding and swollen gums, two remaining teeth slicing into gums, weight loss, and such continuing medical problems."211

Here, continued exposure to toxins has led to serious medical needs. The inmates at SCI Fayette, for example, have serious medical needs for a variety of medical concerns ranging from lung infections to cysts and tumors in the nose, mouth, and throat, to gastrointestinal problems to skin conditions. ${ }^{212}$

While some of these conditions, like shortness of breath, may not be considered "serious" for purposes of an Eighth Amendment claims, others are sufficiently serious because a physician would mandate treatment for something as severe as a tumor, lung infection, or cancer. Additionally, some of the conditions that may seem less serious now might worsen over time if left untreated, as the case with the dentures in Farrow, which would constitute an Eighth Amendment violation. ${ }^{213}$

\section{Deliberate Indifference}

The Supreme Court reasoned that "deliberate indifference" entails more than mere negligence in Estelle v. Gamble. ${ }^{214}$ The Court clarified that a prison official "must both be aware of facts from which the inference could be drawn that a substantial risk of serious harm exists, and he must also draw the inference." 215 The Eleventh Circuit held "deliberate indifference has three components: (1) subjective knowledge of a risk of serious harm; (2) disregard of that risk; (3) by conduct that is more than mere negligence." ${ }^{216}$ Additionally, the Eleventh Circuit has also held that "an official acts with deliberate indifference when he knows that an inmate is in serious need of medical care, but he fails or refuses to obtain medical treatment for the inmate." 217

Once again examining the situation at SCI Fayette, the guards may not have subjective knowledge of a particular inmates' medical needs, however, the Pennsylvania General Assembly had subjective knowledge of the health risks posed at the site because when the dumping started at the site the residents of the nearby town of LaBelle began getting sick. ${ }^{218}$ These residents reported respiratory

West, 320 F.3d 1235, 1243 (11th Cir. 2003)).

210. Colwell v. Bannister, 763 F.3d 1060, 1067 (9th Cir. 2014).

211. Farrow v. West, 320 F.3d 1235, 1244-45 (11th Cir. 2003)).

212. McDaniel, Grote, Fiorillo, Cohen \& Cozzens, supra note 34, at 7-10.

213. Farrow, 320 F.3d at 1244-45.

214. Id. at 1245 .

215. Id. (quoting Farmer v. Brennan, 511 U.S. 825, 837 (1994)).

216. McElligott v. Foley, 182 F.3d 1248, 1255 (11th Cir. 1999).

217. Lancaster v. Monroe County, 116 F.3d 1419, 1425 (11th Cir. 1997).

218. Bernd, Mitra \& Loftus-Farren, supra note 16. 
problems, kidney failure, and cancers, and blamed the dumping site. ${ }^{219}$ However, construction on the prison continued "essentially putting the health of the entire prison population, as well its staff, at risk." 220

Additionally, beyond the evidence in the local community of the risks from this particular coal ash dump, there are known health risks associated with living near these kinds of sites. ${ }^{221}$ "If eaten, drunk or inhaled, these toxicants can cause cancer and nervous system impacts such as cognitive deficits, developmental delays and behavioral problem. They can also cause heart damage, lung disease, respiratory distress, kidney disease, reproductive problems, gastrointestinal illness, birth defects, and impaired bone growth in children.",222 Other health conditions that coal ash can cause include respiratory problems, hypertension, heart problems, brain and nervous system damage, liver damage, and stomach and intestinal ulcers. ${ }^{223}$ Living near a coal ash disposal site can increase your risk of getting cancer and other diseases, according to the EPA. ${ }^{224}$

So, instead of a particular guard having subjective knowledge of a serious harm posed to a particular inmate, this is actually a much more disturbing situation where the Pennsylvania General Assembly knew not only of the specific harm caused to a nearby town but also knew of the harms generally associated with the exposure to coal ash. Therefore, there was subjective knowledge of the risk and the first element of the deliberate indifference analysis is met.

What is more, they decided to build the prison anyway - they disregarded the risk of these serious health concerns by building the prison on the site. ${ }^{225}$ This meets the second element of the deliberate indifference analysis.

Additionally, this conduct was more than mere negligence - the third and final element of the deliberate indifference analysis. ${ }^{226}$ For the conduct to be more than mere negligence it would be reckless. ${ }^{227}$

Reckless misconduct differs from negligence, in that negligence consists of mere inadvertence, incompetence, unskillfulness, or failure to take precautions; reckless misconduct, on the other hand, involves a conscious choice of a course of action, with knowledge or a reason to know that it will create serious danger to others. Recklessness also differs in that it consists of intentionally doing an act with knowledge not only that it contains a risk of harm to others, as does negligence, but that it actually involves a risk substantially greater in magnitude than is necessary in the

\footnotetext{
219. $I d$.

220. $I d$.

221. Coal Ash: Hazardous to Human Health, supra note 27.

222. Id.

223. Bernd, Mitra \& Loftus-Farren, supra note 16.

224. Coal Ash: Hazardous to Human Health, supra note 27.

225. Bernd, Mitra \& Loftus-Farren, supra note 16.

226. McElligott v. Foley, 182 F.3d 1248, 1255 (11th Cir. 1999).

227. 57A AM. JuR. 2D Negligence § 278 (2019).
} 
case of negligence. ${ }^{228}$

Here, there was "a conscious choice of . . . action, with knowledge or a reason to know that it will create serious danger to others" because, as stated previously, the Pennsylvania General Assembly had reason to know that building the prison on the site would cause the adverse health effects already discussed. ${ }^{229}$ Knowing about the health risks associated with exposure to coal ash and consciously choosing to build the prison on the site anyway is reckless and therefore meets the third element of the deliberate indifference analysis. ${ }^{230}$

\section{Causation Between the Defendant's Indifference and the Plaintiff's Injury}

Causation will be the most difficult element of the Cruel and Unusual Punishment claim. ${ }^{231}$ In order to prove causation, there will need to be empirical studies done that prove the connection between the exposures and the harm suffered by inmates, as well as expert testimony that explain that connection. ${ }^{232}$ These are necessary aspects to prove causation and are beyond the scope and capability of this note. However, by examining causation in a toxic tort context, one can understand how the analysis under this element will likely unfold.

In order for tortious conduct to be the cause of an injury, the "conduct must be the "factual cause' of the physical harm to the plaintiff." 233 This is also known as the but-for cause; meaning the "harm would not have occurred absent the conduct." 234

The problem with factual causation in toxic torts is that it is difficult to prove the connection between the exposure to a substance and the development of a health effect, and the plaintiff must prove this connection by a preponderance of the evidence. ${ }^{235}$ This is different from the typical traumatic-injury tort case where, based on reasonable inferences, the defendant's tortious conduct is the only potential cause of the injury. ${ }^{236}$ For example, in a car crash where a passenger breaks an arm, causes other than the accident are easily ruled out-reasonable inferences and experiences allow one to decide that a car crash is capable of

228. Id. (footnotes omitted).

229. Id. (footnote omitted).

230. McElligott, 182 F.3d at 1255.

231. See Restatement (Third) of Torts: Liab. For Physical \& EMotional Harm $§ 28$ (AM. LAW INST. 2010).

232. See id. at cmt. c.

233. June v. Union Carbide Corp., 577 F.3d. 1234, 1239 (10th Cir. 2009) (quoting Restatement (Third) of Torts: Liability for Physical \& EMOtional Harm $§ \S 26,27$ (2010)).

234. Id. at 1240 (quoting Restatement (ThiRd) of Torts: Liability for Physical \& EMOTIONAL HARM $\S \S 26(2010))$.

235. Restatement (ThiRd) OF Torts: Liability for Physical \& EMotional Harm $§ 28$ cmt. c (2010).

236. Id. 
causing a broken arm. ${ }^{237}$ On the other hand, the causes of diseases are not as well understood. ${ }^{238}$

Even known causes for certain diseases may explain only a fraction of the incidence of such diseases, with the remainder due to unknown causes. Causal agents are often identified in group (epidemiologic) studies that reveal an increase in disease incidence among a group exposed to the agent as compared to a group not exposed. Biological mechanisms for disease development - i.e., a series of causally linked physiological changes from exposure to disease development-are frequently complicated and difficult to observe. Science continues to develop a better understanding of the biological steps in the development of diseases, but current knowledge in this respect is considerably more modest than for traumatic injury. As a consequence, courts in toxicsubstances cases often must assess various alternative methods proffered with regard to factual causation. ${ }^{239}$

Because proving causation in toxic torts case is so specific regarding if exposure can cause disease, there is generally testimony from experts about why they believe an exposure could have or could not have caused disease. ${ }^{240}$ Over the years, courts have varied in their standard for admissibility for expert testimony on this point because in some cases, experts differ on whether an exposure can be the cause of an injury. ${ }^{241}$ The Restatement rejects any bright-line for this because "there are instances in which although one scientist or group of scientists comes to one conclusion about factual causation, they recognize that another group that comes to a contrary conclusion might still be "reasonable.",242

However, the substantial factor test is an exception to a but-for cause. ${ }^{243}$ Section 432 of the Restatement (Second of Torts) states: "If two forces are actively operating, one because of the actor's negligence, the other not because of any misconduct on his part, and each of itself is sufficient to bring about harm to another, the actor's negligence may be found to be a substantial factor in bringing it about." 244 Section 433 sets out considerations for "determining whether the actor's conduct is a substantial factor in bringing about harm to another." ${ }^{245}$ Those considerations are:

(a) the number of other factors which contribute in producing the harm

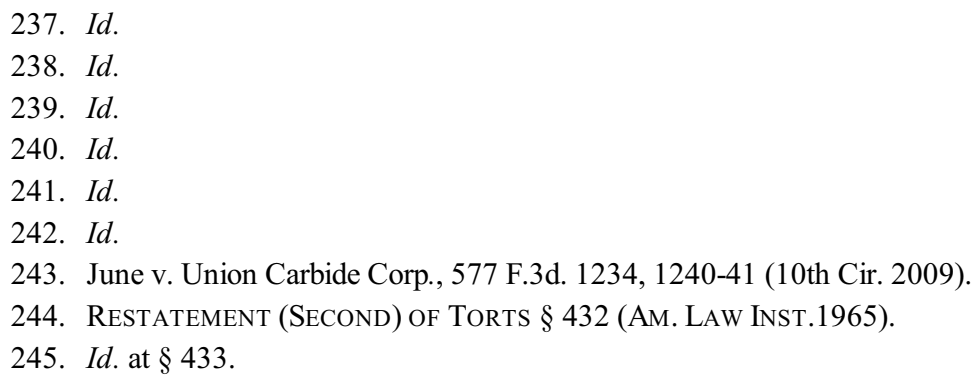


and the extent of the effect which they have in producing it; (b) whether the actor's conduct has created a force or series of forces which are in continuous and active operation up to the time of the harm, or has created a situation harmless unless acted upon by other forces for which the actor is not responsible; (c) lapse of time. ${ }^{246}$

The Court in June v. Union Carbide Corp. explains how all these sections of the Restatement interact with one another, stating, "[o]nce conduct satisfies one of the alternative requirements in $\S 432 \ldots$ which in the Restatement (Third) . . . are the alternative grounds for being a factual cause - it must still qualify under $\S 433$ if it is to be considered a substantial factor." ${ }^{247}$

The substantial factor test is relevant here because, as with many toxic torts cases, there may be more than one factor or exposure that contributed to the inmates' health problems. ${ }^{248}$ And, the exposure can still be the legal but-for cause of the health problems if it was a substantial factor in bringing about those health concerns. ${ }^{249}$ Here, in the case of SCI Fayette, the exposure to coal ash was a substantial factor because the exposure itself was sufficient to bring about the harm to the inmates.

The first consideration of Section 433 of the Restatement, is "the number of other factors which contribute in producing the harm and the extent of the effect which they have in producing it," is difficult to discuss here because one does not know the other factors that might have contributed to a particular inmate's condition. ${ }^{250}$ For example, if an inmate got lung cancer while at SCI Fayette, but also smoked a pack of cigarettes every day, that would be a factor to take into account under this consideration. Without knowing more, one cannot get into this analysis at this time. However, the other two considerations are easier to analyze in this setting.

The second consideration is "whether the actor's conduct has created a force or series of forces which are in continuous and active operation up to the time of the harm or has created a situation harmless unless acted upon by other forces for which the actor is not responsible." ${ }^{251}$ Here, the actor, the Pennsylvania General Assembly, created a force by building the facility next to the dumpsite. ${ }^{252}$ Additionally, that force was in continuous and active operation up to the time of the harm, when the inmates got sick. ${ }^{253}$

The third consideration is "lapse of time." 254 The comments to Section 433 explain that when there has been a long lapse of time it might diminish the effect

246. $I d$.

247. June, 577 F.3d at $1240-41$.

248. See generally Restatement (SECOND) OF TORTs $\S 433$ B cmt. c (Am. LAw Inst. 1965).

249. Id. $\S 431$.

250. Id. § 433.

251. Id.

252. See Bernd, Mitra \& Loftus-Farren, supra note 16.

253. Id.

254. Restatement (SECONd) of Torts $§ 433$ (Am. LAw InSt. 1965). 
of the actor's conduct to where it becomes unsubstantial when compared to other contributing factors. ${ }^{255}$ However, the comments go on to state that "where it is evident that the influence of the actor's negligence is still a substantial factor, mere lapse of time, no matter how long, is not sufficient to prevent it from being the legal cause of the other's harm.. ${ }^{256}$ Here, there was no lapse of time between the exposure and the harm because the inmates were being continuously exposed to the coal ash. ${ }^{257}$

The Abolitionist Law Center and the Human Rights Coalition's twelve-month investigation into the health impacts of exposure to toxic coal waste on the inmates at SCI Fayette found startling health impacts among reporting prisoners, discussed above. ${ }^{258}$ The alarming statistics, however, are probably not enough to prove causation in court. The authors of the investigation seem to agree with this sentiment saying, "the inherent limitations of the survey do not establish this belief at an empirical level." ${ }^{259}$ However, this feels like a strong basis in order to get more parties interested and invested in getting more studies done to prove causation in this case.

When the choice was made to build prisons on toxic land those decisionmakers are deliberately indifferent to the serious medical needs that result from exposure to toxins. This is a form of cruel and unusual punishment and is therefore unconstitutional.

\section{CONCLUSION}

Bringing these constitutional claims may be the wake-up call this country needs regarding the environmental injustices facing our inmate population. However, at its core, this is an attitude problem - a problem with having an indifferent attitude to the health and well-being of the inmates of this country. Yet, the ways in which this indifference has manifested is unconstitutional, and going forward our country needs to either hold in the court or pass laws that prohibit these types of situations and protect our inmates' constitutional rights.

For example, the land on or near FCI Victorville, ADX Florence, and the Northwest Detention Center are all built on or near Superfund sites. ${ }^{260}$ The courts should hold or Congress should pass a law that makes it illegal to build prisons on these sites because the government is forcing people to live on land with known serious health concerns associated with exposures from these sites. Or, when there is a preferred alternative site, like at the Northwest Detention Center, because of hazardous contamination on the other option, the hazardous option should be automatically taken out of the running because of the possible health

255. Id. at $\mathrm{cmt} \mathrm{f}$.

256. Id.

257. See Bernd, Mitra \& Loftus-Farren, supra note 16.

258. McDaniel, Grote, Fiorillo, Cohen \& Cozzens, supra note 34.

259. Id. at 2 .

260. Waters, supra note 46. 
problems that could arise from housing people there. ${ }^{261}$ Indianapolis' new Criminal Justice center presents an opportunity for the proper clean-up and safeguards to be in place before housing inmates on possibly toxic land and causing constitutional rights violations. ${ }^{262}$

Forcing inmates to serve out their time in these toxic prisons is essentially a death sentence for those who never were condemned to such a harsh punishment and is unconstitutional on due process and cruel and unusual punishment grounds. However, this problem represents a bigger problem with how this country values those men and women trapped in our prison system and this country will need to reconsider the worth it puts on an inmate's life.

261. Immigration. \& NAturalization Serv., supra note 53.

262. Indianapolis Breaks Ground on Robust New Criminal Justice Center, supra note 103. 